\title{
ORGANIC RESIDUE, LIMESTONE, GYPSUM, AND PHOSPHORUS ADSORPTION BY LOWLAND SOILS ${ }^{1}$
}

\author{
Alex Teixeira Andrade ${ }^{2 *}$; Luiz Arnaldo Fernandes ${ }^{3}$; Valdemar Faquin ${ }^{4}$ \\ ${ }^{2}$ Pós-Graduando em Solos e Nutrição de Plantas - UFLA. \\ ${ }^{3}$ Núcleo de Ciências Agrárias - UFMG, C.P. 135 - CEP: 39404-006 - Montes Claros, MG. \\ ${ }^{4}$ Depto. Ciência do Solo - UFLA, C.P. 37 - CEP: 37200-000 - Lavras, MG. \\ ${ }^{*}$ Corresponding author <alext@ufla.br>
}

\begin{abstract}
Organic residue application is a low cost alternative to reduce the use of inorganic fertilizers and correctives. In order to study the effect of organic residues, limestone and gypsum application on phosphorus adsorption by lowland soils, four experiments were carried out. A Mesic Organosol (OY), a Melanic Gleysol (MG), a Haplic Gleysol (GX), and a Fluvic Neosol (RU) were used in a completely randomized design and factorial scheme $(3 \times 2)$, with five replicates: three soil amendment practices (limestone, gypsum and no corrective) and two levels of organic residue (with and without corral manure). Soil samples were incubated for 60 days, with and without organic residue incorporation. After this period, we applied the corrective and incubated the soil for 30 days, then $\mathrm{P}$ and basic fertilization (macro and micronutrients) were applied and the soil was incubated for additional 60 days. Equilibrium phosphorus, maximum phosphate adsorption capacity, $\mathrm{pH}$, exchangeable Al and phosphorus-buffering index were measured. Organic residue and limestone application increased soil pH and reduced exchangeable $\mathrm{Al}$, decreasing $\mathrm{P}$ adsorption. Gypsum application did not increase the $\mathrm{pH}$ but reduced exchangeable $\mathrm{Al}$ and $\mathrm{P}$ adsorption.
\end{abstract}

Key words: liming, gypsum, organic matter

\section{RESÍDUO ORGÂNICO, CALCÁRIO E GESSO E A ADSORÇÃO DE FÓSFORO POR SOLOS DE VÁRZEA}

\begin{abstract}
RESUMO: A aplicação de resíduo orgânico é uma alternativa de baixo custo para reduzir a aplicação de fertilizantes inorgânicos e corretivos. Com objetivo de estudar a relação da aplicação de resíduo orgânico, calcário e gesso com adsorção de fósforo em solos de várzea conduziram-se simultaneamente quatro experimentos com os solos Organossolo Mésico (OY), Gleissolo Melânico (GM), Gleissolo Háplico (GX) e Neossolo Flúvico (RU). O delineamento experimental utilizado foi o inteiramente casualizado, em esquema fatorial 3x2, com cinco repetições, sendo três práticas de correção do solo (calcário, gesso e sem corretivo) e dois níveis de resíduo orgânico com e sem esterco de curral curtido. Amostras dos solos foram incubadas por 60 dias com e sem incorporação do resíduo orgânico; após este período, por mais 30 dias com os corretivos e em seguida por 60 dias com o fósforo e uma adubação básica com macro e micronutrientes. Determinaram-se o fósforo remanescente, capacidade máxima de adsorção de fósforo, $\mathrm{pH}, \mathrm{Al}$ trocável e índice tampão de fósforo. A aplicação de resíduo orgânico, calcário - pela elevação do pH e redução dos teores de Al trocável - e gesso - pela redução de Al trocável - reduzem a adsorção de fósforo nos solos de várzea estudados.

Palavras-chave: calagem, gessagem, matéria orgânica
\end{abstract}

\section{INTRODUCTION}

Application of organic residues to soils reduces phosphorus adsorption and increases phosphate fertilizer efficiency (Hue, 1990). This is an interesting practice, specially for developing countries, due to its low cost and to the fact that it reduces expenses with inorganic fertilizers and correctives (lyamuremye et al., 1996). For soils in flooded-drained conditions, organic residue addition decreases phosphorus adsorption and alteres phosphate fractions; mainly organic fractions, which correspond to more than $50 \%$ of total $\mathrm{P}$ in these soils (Sah et al., 1989).

Flooded soil conditions influenced phosphorus dynamics, raising its availability, which is attributed to: ferric phosphate reduction to ferrous phosphate, phosphates and organic anion hydrolyses, phosphorus displacement from iron and aluminum phosphates by chelate agents produced by anaerobic decomposition of organic matter, phosphorus release from organic matter, phosphorus release in limestone soils and removal of hydrated iron oxide that recovers phosphates due to iron reduction (Ponnamperuma, 1972). However, when a flooded rice field is drained, a reoxidation of soil components that were reduced occurs due to changes in oxidation-reduction potential, $\mathrm{pH}$ and $\mathrm{Fe}^{2+}$ concentration, which decreases the solubility of background and added phosphorus (Sayal \& De Datta, 1991). The lower $P$ availability in drained soils is associated to $\mathrm{P}$ adsorption increase owing to iron oxide activity increase (Willett \& Higgins, 1978). 
Organic acid type and amount depend on the carbon source and microorganism species existing. The quality of the released organic acids is more important than their quantity. Acids that form chelates are the most effective (Sperber, 1958). This is a property of hydroxyacids, sugar-acids, aromatic composts, humic substances and others (Nahas, 1991). Carboxylic functional groups $(\mathrm{COOH})$ of organic acids strongly react with $\mathrm{P}$ adsorption sites on iron and aluminum oxides, making these sites less accessible to $P$ (Hue, 1991).

Sibanda \& Young (1986) studied phosphates, humic and fulvic acids competitive adsorption by two tropical soils. They verified that there was a significant reduction of phosphorus adsorption when humic acid content was elevated from 0.7 to $3.0 \%$, which are levels equivalent to organic matter content increases of 1.72 to $5.2 \%$. In addition they observed, for the highest fulvic acid level (3\%), phosphorus adsorption reduction of 68 and $48 \%$ respectively for soils with $\mathrm{pH} 4.6$ and 5.1 . This shows that the more acid is the soil, the more pronounced is the organic acid influence.

The role of organic acids in phosphorus adsorption decrease can not only be attributed to complex and chelate formation with iron and aluminum (Iyamuremye et al., 1996). An additional mechanism to be considered is phosphate, sulfate, fluorine and calcium release due to residue decomposition. Sulfate and fluorine form complexes with iron and aluminum. Calcium can form soluble composts with phosphorus in soil solution, avoiding phosphorus adsorption.

Interactions of organic residue in the soil can have a similar effect to that of limestone (calcium and magnesium carbonate) due to iron and aluminum precipitation (Hue, 1992), or to gypsum (calcium sulfate) due to exchangeable aluminum complexation (Ritchey et al., 1980). However, the knowledge of the effects when organic residue is added to soils under flooded-drained conditions is limited and results have been contradictory (lyamuremye \& Dick, 1996). Therefore, further studies are necessary to compare residues to inorganic correctives, as gypsum, which reduces exchangeable iron and aluminum contents without altering soil $\mathrm{pH}$ significantly; or as limestone, which increases $\mathrm{pH}$ and reduces exchangeable iron and aluminum. Comparing gypsum to limestone, effects can provide a better understanding on how organic residues affect phosphorus adsorption by soils and its phytoavailability.

The objective of this study was to verify organic residue, limestone and gypsum incorporation effects on phosphorus adsorption by four lowland soils.

\section{MATERIAL AND METHODS}

Four greenhouse experiments were conducted, using four lowland soils, located at the Soil Science Department of Lavras Federal University, in plastic pots (capacity of four $\mathrm{dm}^{3}$ ), filled with $3 \mathrm{dm}^{3}$ of soil.
Soils classes used were Mesic Organosol (OY), Melanic Gleysol (MG), Haplic Gleysol (GX) and Fluvic Neosol (RU). These soils are the main lowland soils in Minas Gerais state (Embrapa, 1982) and were collected in a private farm in the city of Lavras (Southeast Brazil).

Soil samples were collected from the top layer between 0 to $0.2 \mathrm{~m}$ depth, under natural vegetation. Special care was taken to remove all vegetation and organic material from soil surface. The samples were airdried and ground to pass through a $4 \mathrm{~mm}$ sieve. To determine some physical, chemical and mineralogical attributes, part of the samples were ground again to pass through a $2 \mathrm{~mm}$ sieve (fine-grained soil) (Table 1 ).

For each experiment, a $3 \times 2$ factorial design was used, completely randomized, with five replicates: three soil amendment practices (limestone, gypsum and no corrective) and two levels of organic residue (with and without).

Corral manure was the used organic residue. It was dried at $60^{\circ} \mathrm{C}$ and ground to pass through a $1 \mathrm{~mm}^{2}$ sieve. The amount added was $0.3 \mathrm{dm}^{3}$ to each pot, which corresponds to $10 \%$ of total pot volume, as indicated by lyamuremye et al. (1996). Residue was analyzed for $\mathrm{N}$ (Kjeldahl), P, K, Ca, Mg, S, Cu, Fe, Mn and $\mathrm{Zn}$ (nitricperchloric digestion) and $\mathrm{B}$ (incineration) following the methodology suggested by Malavolta et al. (1997). Results are shown in Table 2. Then, pots were filled according to each treatment, followed by a 60 days incubation period. Field capacity was maintained, $70 \%$ of total pore volume was occupied by water (Freire et al., 1980).

After the incubation period, soils were dried and the correctives added. Limestone $\left(\mathrm{CaCO}_{3}+\mathrm{MgCO}_{3}\right)_{4}$ $\mathrm{Mg}(\mathrm{OH})_{2} \cdot 5 \mathrm{H}_{2} \mathrm{O}$ p.a. in the ratio Ca:Mg of $4: 1$ ) rates were established using incubation curves, aiming to elevate bases saturation ( $\mathrm{V} \%$ ) to $70 \%$ (Azevedo, 1999). The rates were respectively, 3.5, 7.3, 2.7 and $4.4 \mathrm{t} \mathrm{ha}^{-1}$, to OY, MG, $\mathrm{GX}$ and $\mathrm{RU}$ soils. Gypsum $\left(\mathrm{CaSO}_{4} \cdot 4 \mathrm{H}_{2} \mathrm{O}\right.$ p.a.) rates were calculated to add the same $\mathrm{Ca}$ amount added by limestone, for each soil. To gypsum treatments, $\mathrm{Mg}$ $\left(\mathrm{MgSO}_{4} \cdot 7 \mathrm{H}_{2} \mathrm{O}\right.$ p.a. form) was also added in the same amount that was added by limestone, to avoid nutritional unbalance in bean plants. Soils treated with or without limestone or gypsum were incubated for more 30 days, maintaining humidity correspondent to field capacity and $70 \%$ of total pore volume occupied by water.

Soils incubated with correctives were sampled and dried. Phosphorus was added in doses that allow to reach $90 \%$ of maximum bean production. The rates were 299, 460, 359 and $345 \mathrm{mg} \mathrm{dm}^{-3}$ of $P$ to OY, MG, GX and $\mathrm{RU}$ soils, respectively, as indicated by Fernandes et al. (2000). A fertilization with macro and micronutrients was also done: $60 \mathrm{mg}$ of $\mathrm{N} 50 \mathrm{mg}$ of $\mathrm{K}, 60 \mathrm{mg}$ of $\mathrm{S} 0.5 \mathrm{mg}$ of $\mathrm{B}, 1.5 \mathrm{mg}$ of $\mathrm{Cu}$ and $5.0 \mathrm{mg}$ of $\mathrm{Zn}$ per $\mathrm{dm}^{-3}$ of soil, using p.a. reagents. Sources used were: $\mathrm{Ca}\left(\mathrm{H}_{2} \mathrm{PO}_{4}\right)_{2} \cdot \mathrm{H}_{2} \mathrm{O}$; $\mathrm{MgSO}_{4} \cdot 7 \mathrm{H}_{2} \mathrm{O} ; \mathrm{Mg}\left(\mathrm{NO}_{3}\right)_{2} \cdot 6 \mathrm{H}_{2} \mathrm{O} ; \mathrm{KCl} ; \mathrm{ZnSO}_{4} \cdot 7 \mathrm{H}_{2} \mathrm{O}$; 
$\mathrm{CuCl}_{2} \cdot 2 \mathrm{H}_{2} \mathrm{O}$ and $\mathrm{H}_{3} \mathrm{BO}_{3}$. After these additions another 60 days incubation period was maintained at field capacity and $70 \%$ of total pore volume occupied with water (Freire et al., 1980). Then, samples were collected from each pot for analytical determinations.

Part of the samples were air-dried and ground to pass through a $2 \mathrm{~mm}$ sieve (fine-grained soil) to carry out the following determinations: remaining $P$ (P-rem), maximum phosphate adsorption capacity (MPAC), $\mathrm{pH}$, exchangeable $\mathrm{Al}$ and phosphorus-buffering index (PBI). Remaining phosphorus determination was performed according to Alvarez V. et al. (2000). Phosphorus in equilibrium solution was measured using the $C$ vitamin method, modified by Braga \& Defelipo (1974).

Phosphorus rates used to determinate maximum phosphate adsorption capacity were chosen based on P-rem values, as indicated by Alvarez V. \& Fonseca (1990). For $3 \mathrm{dm}^{-3}$ soil samples $30 \mathrm{~mL}$ of $10 \mathrm{mmol} \mathrm{L}^{-1}$ $\mathrm{CaCl}_{2}$ solution with $\mathrm{P}$ in a content according to each soil and treatment were added, followed by a shaking period of 24 hours. After this, soil:solution mixture was centrifuged and filtered and $P$ in the equilibrium solution was quantified using a colorimetric method (Braga \& Defelipo, 1974). Sorbed phosphorus values were adjusted to a Langmuir isotherm to estimate MPAC (Syers et al., 1973; Rajan \& Fox, 1975), according to the equation: $q=(k b C) /(1+k C)$, where $q=$ sorbed phosphorus $\left(\mathrm{mg} \mathrm{dm}^{-3}\right), \mathrm{k}=$ constant related to $\mathrm{P}$ binding energy $\left(L \mathrm{mg}^{-1}\right), \mathrm{b}=$ soil MPAC $\left(\mathrm{mg} \mathrm{dm}^{-3}\right)$, and $C=$ equilibrium concentration.

After centrifugation and supernatant discard, other $30 \mathrm{~mL}$ of $10 \mathrm{mmol} \mathrm{L}^{-1} \mathrm{CaCl}_{2}$ were added to the same soil samples, followed again by a 24 hour shaking period. Then, soil:solution mixture was centrifuged and filtered and $P$ in supernatant quantified by a colorimetric method (Braga \& Defelipo, 1974) to determinate desorbed $\mathrm{P}$ content.

Second-degree regression equations were fitted to plots of sorbed and desorbed $P$ obtained for the different $P$ contents added in each treatment. The $b$ coefficients of these equations were used to estimate phosphorus-buffering index (PBI), as indicated by Accioly et al. (1985) and modified for P by Guilherme et al. (2000). The $\mathrm{pH}$ determination was made in water, using the relation soil:solution of 1:2.5. Exchangeable $\mathrm{Al}$ was extracted with $1 \mathrm{~mol} \mathrm{~L}^{-1} \mathrm{KCl}$ (EMBRAPA, 1997).

All studied parameters were submitted to analysis of variance. Treatments with limestone and gypsum or without corrective were compared by the Scott Knott test. P-rem, MPAC, PBI, $\mathrm{pH}$ and Al multiple correlation was performed.

Table 1 - Chemical, physical and mineralogical soil attributes before limestone, gypsum and/or organic residue addition.

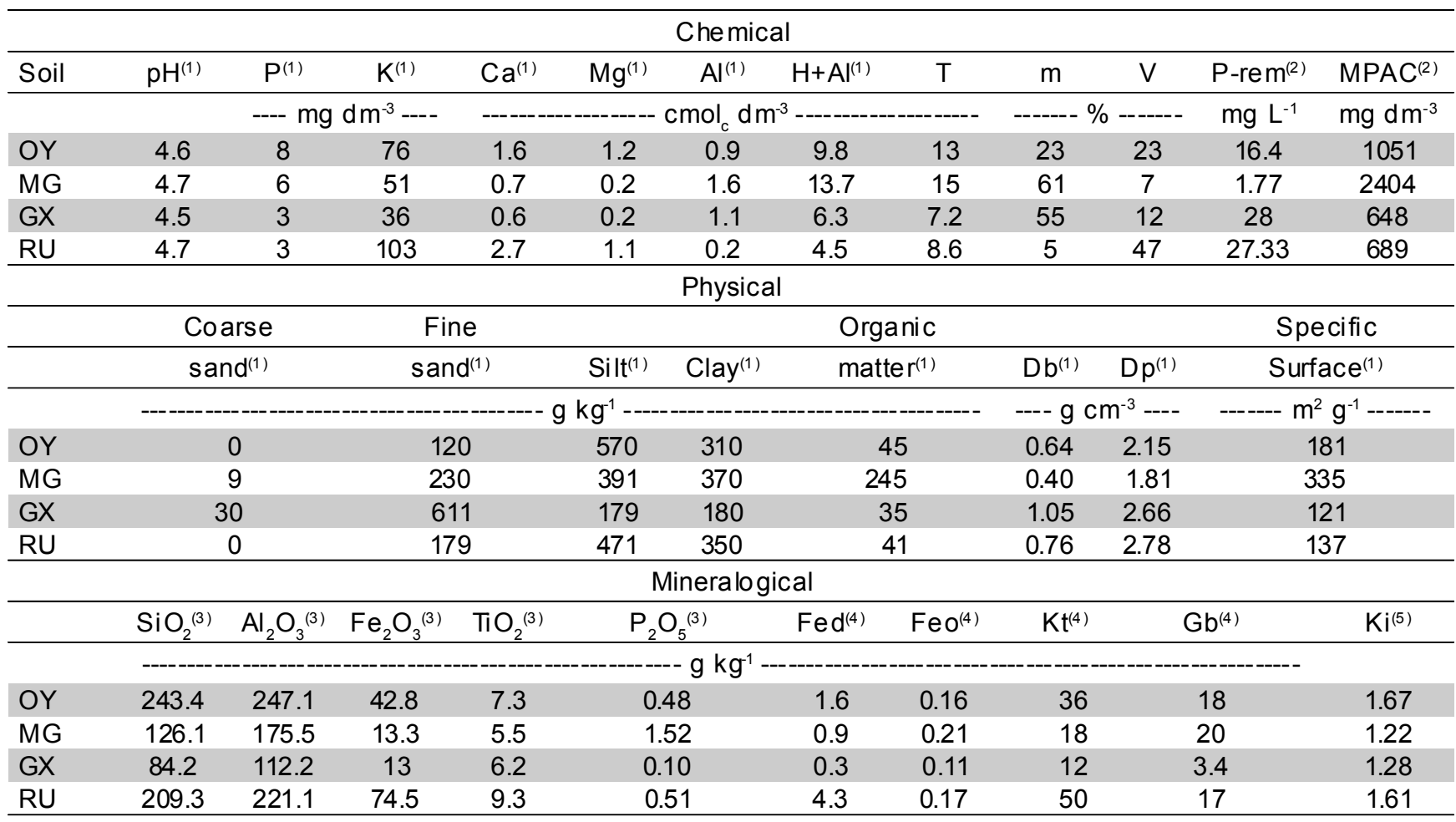

(1) $\mathrm{pH}=\mathrm{pH}$ in water; $\mathrm{P}=$ phosphorus extracted by Mehlich $1 ; \mathrm{K}=$ potassium; $\mathrm{Ca}=$ calcium; $\mathrm{Mg}=$ magnesium; $\mathrm{Al}=$ aluminum; $\mathrm{H}+\mathrm{Al}=$ potential acidity; $\mathrm{T}=$ cation exchange capacity $(\mathrm{pH} 7.0) ; \mathrm{m}=\mathrm{Al}$ saturation and $\mathrm{V}=$ bases saturation; $\mathrm{Db}=$ bulk density; $\mathrm{Dp}=\mathrm{particle}$ density; (EMBRAPA, 1997); (2)P-rem = remaining P (Alvarez V. et al., 2000) and MPAC = maximum phosphorus adsorption capacity (Alvarez V. \& Fonseca, 1990); ${ }^{(3)}$ Sulfuric acid attack extractable oxides (EMBRAPA, 1997); ${ }^{(4)} \mathrm{Fe}_{\mathrm{d}}=$ dithionite-citrate-bicarbonate extractable iron (Mehra \& Jackson, 1960); $\mathrm{Fe}_{\mathrm{o}}=$ iron extracted by acid ammonium oxalate extractable iron; $\mathrm{Kt}=\mathrm{kaolinite} ; \mathrm{Gb}=$ gibbsite (both in clay fraction and corrected to fine soil) . ${ }^{(5)} \mathrm{Ki}-$ molecular relation: $\mathrm{SiO}_{2} / \mathrm{Al}_{2} \mathrm{O}_{3}$. 


\section{RESULTS AND DISCUSSION}

$P$-rem is part of $P$ added that remains in the equilibration solution after a defined time in contact with the soil. It was found in large amounts in treatments that received organic residue, regardless soil type or soil correction practice used, except for Fluvic Neosol (RU) treated with limestone (Table 3 ). Treatments with organic residue, despite of corrective use, presented values for P-rem 31\% (OY), 36\% (MG), 26\% (GX) and $9 \%(\mathrm{RU})$ higher than treatments without residue (Figure 1 ). This can be attributed to the fact that organic compounds, released by residue decomposition, occupy $P$ adsorption sites on iron and aluminum oxides surfaces. Fontes et al. (1992) found that functional groups $(\mathrm{COOH})$ occupy goethite surface, for instance, reducing drastically $P$ adsorption. In fact, these functional groups react with hydroxyls of iron or aluminum oxides (Hue, 1991). Therefore, as suggested by Silva et al. (1997), practices that increase organic matter in soils possibly contribute to $\mathrm{P}$ adsorption reduction. This is an interesting alternative to maximize phosphate fertilization, mainly for developing countries, where farmers have financial difficulties to purchase fertilizers (lyamurenye et al., 1996).

Regardless of soil type and organic residue addition, the highest $\mathrm{P}$-rem values were observed in limestone treatments, except for GX and RU soils, for which no difference between corrective practices was found (Table 3). Limestone is a corrective that neutralizes exchangeable Al and $\mathrm{Fe}$ and increases soil $\mathrm{pH}$. However, gypsum can reduce Al activity in soil solution, but just slight changes in soil pH were observed.

The lowest P-rem values for MG soil could be attributed to the highest $\mathrm{Fe}$ oxalate (Table 1) and amorphous aluminum contents (Fernandes, 1999). This author verified a positive correlation between amorphous $\mathrm{Al}$ and $\mathrm{P}$ adsorption. The large amount of amorphous $\mathrm{Al}$ in the MG soil could be related to its high organic matter content in relation to the other studied soils, since organic anions interfere in $\mathrm{Al}(\mathrm{OH})_{3}$ crystallization (Goh \& Huang, 1985).

Increase in soil $\mathrm{pH}$ and decrease in exchangeable Al probably cause higher P-rem values when organic residue is added (Table 3 ). Although in this study soil $\mathrm{pH}$ values in limestone and gypsum treatments (except for gypsum in GX and RU soils) were higher than treatments with organic residue addition alone, the last significantly contributes to P-rem increase. It was also verified that treatments with organic residue addition alone, regardless of the corrective practice, presented the lowest exchangeable Al values. For limestone and gypsum treatments, residue decreased exchangeable $\mathrm{Al}$ in $84 \%, 51 \%$ and $80 \%$ for OY, MG and RU soils, respectively (Figure 2). Hargrove \& Thomas (1981) observed that when organic matter content increases, even in little amounts, soluble Al removal occurred. In this case, limestone addition was not necessary due

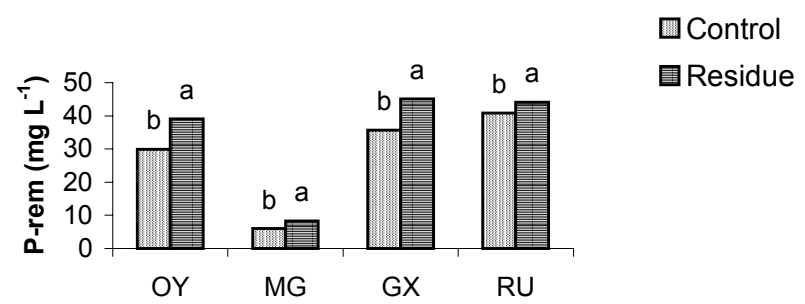

Figure 1 - P-rem values for Mesic Organosol (OY), Melanic Gleysol (MG), Haplic Gleysol (GX) and Fluvic Neosol (RU) soils, without (control) or with organic residue addition, regardless corrective practices used. For each soil, means followed by same letter are not significantly different (Test $\mathrm{F}, \mathrm{p}<0.01)$.

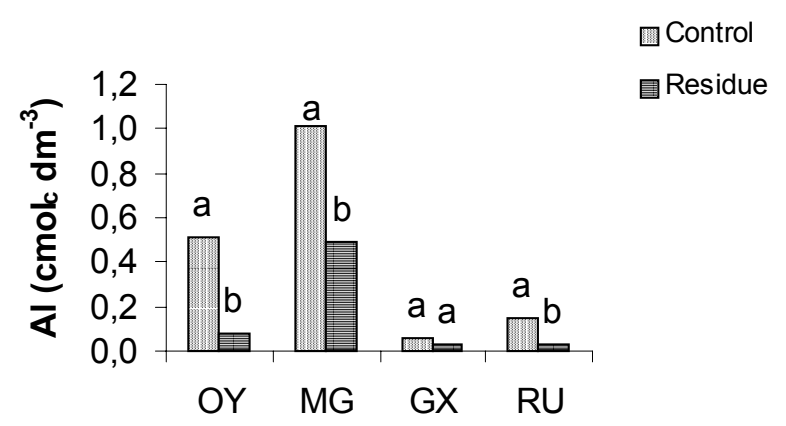

Figure 2 - Mesic Organosol (OY), Melanic Gleysol (MG), Haplic Gleysol (GX) and Fluvic Neosol (RU) exchangeable Al, without (control) and with organic residue addition, regardless soil correction practice used. For each soil, means followed by same letter are not significantly different (Test $F, p<0.01$ ).

Table 2 - Total nutrient content and amount added by residue.

\begin{tabular}{|c|c|c|c|c|c|}
\hline Macronutrient & Total content & Amount added & Micronutrient & Total content & Amount added \\
\hline & ----- g kg$^{-1}$ & ---- $\mathrm{g} \mathrm{dm}^{-3}$ & & --- $\mathrm{mg} \mathrm{kg}^{-1}$ & $---\mathrm{mg} \mathrm{dm}^{-3}$ \\
\hline $\mathrm{N}$ & 19.73 & 0.721 & $\mathrm{Mn}$ & 808.5 & 29.556 \\
\hline $\mathrm{P}$ & 4.50 & 0.164 & $\mathrm{Fe}$ & 52066 & 1903 \\
\hline K & 45.00 & 1.645 & $\mathrm{Cu}$ & 52.73 & 1.927 \\
\hline$S$ & 3.00 & 0.109 & B & 19.34 & 0.707 \\
\hline $\mathrm{Ca}$ & 26.40 & 0.965 & $\mathrm{Zn}$ & 108.17 & 3.654 \\
\hline $\mathrm{Mg}$ & 4.56 & 0.166 & & & \\
\hline
\end{tabular}

${ }^{1}$ Residue density: $365 \mathrm{~g} \mathrm{dm}^{-3}$. 
to complex formation. In addition, $\mathrm{H}^{+}$ion removal from soil solution caused a $\mathrm{pH}$ raise, and exchangeable $\mathrm{Al}$ was hydrolyzed, resulting in $\left(\mathrm{Al}\left(\mathrm{H}_{2} \mathrm{O}\right)_{5} \mathrm{OH}\right)^{2+}$ and $\left(\mathrm{Al}\left(\mathrm{H}_{2} \mathrm{O}\right)_{4}(\mathrm{OH})_{2}\right)^{+}$. These Al monomers are not available to be chelated by soil organic matter, being polymerized in clay mineral surfaces and not being part of soil exchangeable acidity (McLean, 1973). Depending on $\mathrm{pH}$, complete $\mathrm{Al}$ hydrolysis can occur, resulting in $\mathrm{Al}(\mathrm{OH})_{3} \cdot 3 \mathrm{H}_{2} \mathrm{O}$. This hydroxide crystallizes, forming gibbsite, which can release Al to soil solution again in acid conditions (Lindsay, 1979).

Organic residue effect on soil $\mathrm{pH}$ (Figure 3 ), as reported by Hue (1992), could be attributed to carbon mineralization, "basic" cation release and $\mathrm{OH}^{-}$release owing to $\mathrm{Mn}$ reduction or $\mathrm{Fe}$ reduction of anaerobic microsites. The $\mathrm{pH}$ increase could be attributed to ion production on ligand exchange sites, that occurs with

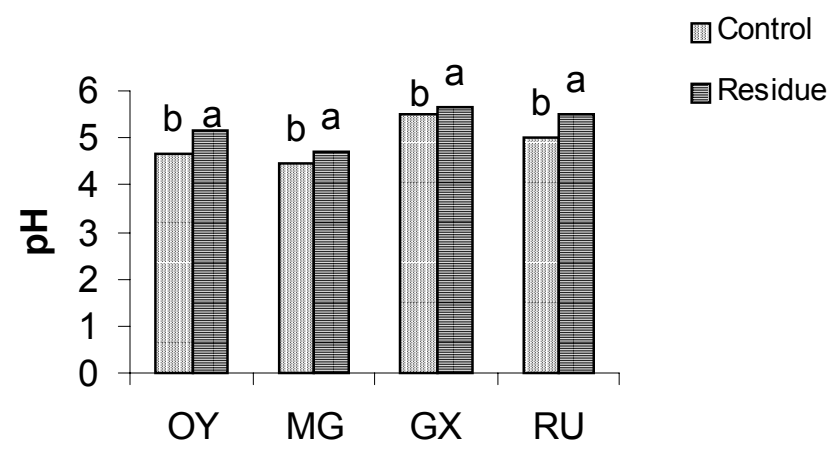

Figure 3 - Mesic Organosol (OY), Melanic Gleysol (MG), Haplic Gleysol (GX) and Fluvic Neosol (RU) pH, without (control) and with organic residue addition, regardless soil correction practice used. For each soil, means followed by same letter are not significantly different (Test $F$, $\mathrm{p}<0.01)$.

Table 3 - Remaining phosphorus (P-rem), maximum phosphate adsorption capacity (MPAC), phosphorus-buffering index (PBI), $\mathrm{pH}$ and Al for Mesic Organosol (OY), Melanic Gleysol (MG), Haplic Gleysol (GX) and Fluvic Neosol (RU) soils treated with different corrective practices, with and without organic residue addition.

\begin{tabular}{|c|c|c|c|c|c|c|c|}
\hline SOIL & $\begin{array}{c}\text { Corrective } \\
\text { practice }\end{array}$ & Residue & P-rem & MPAC & PBI & $\mathrm{pH}$ & Al \\
\hline \multirow{10}{*}{ OY } & & & $\mathrm{mg} \mathrm{L}^{-1}$ & $\mathrm{mg} \mathrm{dm}^{-3}$ & & & $\mathrm{cmol}_{\mathrm{c}} \mathrm{dm}^{-3}$ \\
\hline & Without & without & $28.44 \mathrm{~b}$ & $774.66 \mathrm{a}$ & $15.198 \mathrm{a}$ & $4.36 \mathrm{~b}$ & $0.88 a$ \\
\hline & Corrective & with & $40.09 a$ & $586.95 b$ & $10.524 b$ & $4.94 \mathrm{a}$ & $0.10 \mathrm{~b}$ \\
\hline & & Mean & $34.265 \mathrm{~B}$ & $680.805 \mathrm{~B}$ & $12.861 \mathrm{~B}$ & $4.65 \mathrm{C}$ & $0.49 \mathrm{~A}$ \\
\hline & Limestone & without & $32.69 \mathrm{~b}$ & 666.70 a & $18.347 a$ & $5.00 \mathrm{~b}$ & $0.18 a$ \\
\hline & & with & $39.66 \mathrm{a}$ & $583.17 b$ & $10.223 b$ & $5.46 \mathrm{a}$ & $0.00 \mathrm{~b}$ \\
\hline & & Mean & $36.175 \mathrm{~A}$ & $624.93 \mathrm{C}$ & $14.285 \mathrm{~A}$ & $5.23 \mathrm{~A}$ & $0.09 \mathrm{C}$ \\
\hline & Gypsum & without & $28.58 \mathrm{~b}$ & $784.63 a$ & $15.878 \mathrm{a}$ & $4.56 \mathrm{~b}$ & $0.46 a$ \\
\hline & & with & $37.48 \mathrm{a}$ & $627.09 \mathrm{~b}$ & $10.590 \mathrm{~b}$ & $5.06 \mathrm{a}$ & $0.14 \mathrm{~b}$ \\
\hline & & Mean & $33.03 \mathrm{~B}$ & $705.86 \mathrm{~A}$ & 13.234 B & $4.81 \mathrm{~B}$ & $0.30 \mathrm{~B}$ \\
\hline \multirow{9}{*}{$M G$} & Without & without & $4.91 \mathrm{~b}$ & 2023.66 a & $175.454 \mathrm{a}$ & $4.26 \mathrm{~b}$ & $1.50 \mathrm{a}$ \\
\hline & Corrective & with & $8.43 a$ & 2026.93 a & $120.138 b$ & $4.56 \mathrm{a}$ & $0.72 \mathrm{~b}$ \\
\hline & & Mean & $6.67 \mathrm{~B}$ & 2025.29 A & $147.79 \mathrm{~A}$ & $4.41 \mathrm{C}$ & $1.11 \mathrm{~A}$ \\
\hline & Limestone & without & $7.11 \mathrm{~b}$ & $2005.74 a$ & $150.798 a$ & $4.68 \mathrm{~b}$ & $0.52 a$ \\
\hline & & with & $8.24 \mathrm{a}$ & $1985.04 \mathrm{a}$ & $101.76 \mathrm{~b}$ & $4.94 \mathrm{a}$ & $0.20 \mathrm{~b}$ \\
\hline & & Mean & $7.675 \mathrm{~A}$ & $1995.39 \mathrm{~B}$ & 126.27 B & $4.81 \mathrm{~A}$ & $0.36 \mathrm{C}$ \\
\hline & Gypsum & without & $6.1 \mathrm{~b}$ & $2017.98 a$ & $197.862 \mathrm{a}$ & $4.50 \mathrm{~b}$ & $1.00 \mathrm{a}$ \\
\hline & & with & $7.97 \mathrm{a}$ & $1953.15 \mathrm{~b}$ & $92.219 \mathrm{~b}$ & $4.60 \mathrm{a}$ & $0.54 \mathrm{~b}$ \\
\hline & & Mean & $7.035 \mathrm{~B}$ & $1985.56 \mathrm{~B}$ & 145.04 A & $4.55 \mathrm{~B}$ & $0.77 \mathrm{~B}$ \\
\hline \multirow{9}{*}{ GX } & Without & without & $33.85 \mathrm{~b}$ & $615.66 \mathrm{a}$ & $8.331 \mathrm{a}$ & $5.22 \mathrm{~b}$ & $0.14 \mathrm{a}$ \\
\hline & Corrective & with & $43.77 \mathrm{a}$ & 375.94 b & $2.40 \mathrm{~b}$ & $5.52 \mathrm{a}$ & $0.00 \mathrm{~b}$ \\
\hline & & Mean & $38.81 \mathrm{~A}$ & $495.80 \mathrm{~A}$ & $5.365 \mathrm{~A}$ & $5.37 \mathrm{~B}$ & $0.07 \mathrm{~A}$ \\
\hline & Limestone & without & $39.13 \mathrm{~b}$ & $575.25 \mathrm{a}$ & $8.047 \mathrm{a}$ & $5.90 \mathrm{a}$ & $0.00 \mathrm{a}$ \\
\hline & & with & $43.25 \mathrm{a}$ & $356.42 \mathrm{~b}$ & $3.576 \mathrm{~b}$ & $6.02 \mathrm{a}$ & $0.00 a$ \\
\hline & & Mean & $41.19 \mathrm{~A}$ & $465.835 \mathrm{~B}$ & $5.811 \mathrm{~A}$ & $5.96 \mathrm{~A}$ & $0.00 \mathrm{~B}$ \\
\hline & Gypsum & without & $34.21 \mathrm{~b}$ & $626.10 \mathrm{a}$ & $5.286 \mathrm{a}$ & $5.44 \mathrm{a}$ & $0.04 a$ \\
\hline & & with & $44.84 \mathrm{a}$ & $288.69 \mathrm{~b}$ & $2.550 \mathrm{~b}$ & $5.48 \mathrm{a}$ & $0.10 a$ \\
\hline & & Mean & $39.525 \mathrm{~A}$ & $457.395 \mathrm{~B}$ & $3.918 \mathrm{~B}$ & $5.46 \mathrm{~B}$ & $0.07 \mathrm{~A}$ \\
\hline \multirow{9}{*}{$\mathrm{RU}$} & Without & without & $41.76 \mathrm{~b}$ & $512.67 \mathrm{a}$ & $16.295 \mathrm{a}$ & $4.66 \mathrm{~b}$ & $0.20 \mathrm{a}$ \\
\hline & Corrective & with & $47.13 a$ & $375.48 \mathrm{~b}$ & $6.521 \mathrm{~b}$ & $5.34 \mathrm{a}$ & $0.00 \mathrm{~b}$ \\
\hline & & Mean & $44.445 \mathrm{~A}$ & $444.075 \mathrm{~B}$ & $11.408 \mathrm{~B}$ & $5.00 \mathrm{~B}$ & $0.10 \mathrm{~B}$ \\
\hline & Limestone & without & $41.9 a$ & $553.51 \mathrm{a}$ & $16.026 \mathrm{a}$ & $5.62 b$ & $0.04 a$ \\
\hline & & with & $42.82 \mathrm{a}$ & $402.62 \mathrm{~b}$ & $9.227 \mathrm{~b}$ & $5.96 \mathrm{a}$ & $0.00 \mathrm{~b}$ \\
\hline & & Mean & $42.36 \mathrm{~B}$ & $478.065 \mathrm{~A}$ & $12.626 \mathrm{~B}$ & $5.79 \mathrm{~A}$ & $0.02 \mathrm{C}$ \\
\hline & Gypsum & without & $38.79 \mathrm{~b}$ & $523.70 \mathrm{a}$ & $20.328 a$ & $4.72 \mathrm{~b}$ & $0.20 \mathrm{a}$ \\
\hline & & with & $43.52 a$ & $401.69 \mathrm{~b}$ & $8.382 \mathrm{~b}$ & $5.22 \mathrm{a}$ & $0.10 \mathrm{~b}$ \\
\hline & & Mean & $41.155 \mathrm{~B}$ & $462.695 \mathrm{~A}$ & $14.355 \mathrm{~A}$ & $4.97 \mathrm{~B}$ & $0.15 \mathrm{~A}$ \\
\hline
\end{tabular}

Minute letters compare treatments with and without residue for each soil and corrective practice used. Capital letters compare corrective practices for each soil, regardless residue addition. 
organic acids on $\mathrm{Al}$ and $\mathrm{Fe}$ hydroxide surfaces (lyamuremye et al., 1996). These authors observed that $\mathrm{pH}$ increase causes exchangeable $\mathrm{Fe}$ and $\mathrm{Al}$ precipitation, reducing phosphorus precipitation potential.

lyamuremye et al. (1996) verified that animal and alfalfa organic residues, as wel as calcium carbonate, reduced $100 \%$ of exchangeable Al content. Wheat residue was less effective, reducing only $58-78 \%$, and calcium sulfate was even less effective.

Exchangeable $\mathrm{Al}$ content reduction due to organic residue and calcium carbonate addition could be explained by a $\mathrm{pH}$ increase. This reduction could be caused by Al precipitation with hydroxyls produced by ligand exchange site mechanisms that occur with organic acids at the surface of $\mathrm{Al}$ and $\mathrm{Fe}$ oxides, or by complexation with organic molecules (Hue, 1992). It is also possible that during organic residue decomposition, sulfate is released to soil solution, decreasing exchangeable Al content. Sulfate effect in exchangeable Al decrease could be observed in gypsum treatments (Table 3). Alva \& Sumner (1989) also verified exchangeable $\mathrm{Al}$ reduction owing to complexation with sulfate ions.

A positive correlation was found between P-rem and $\mathrm{pH}$, and a negative one with exchangeable $\mathrm{Al}$, confirming soil $\mathrm{pH}$ and exchangeable $\mathrm{Al}$ effects on P-rem (Table 4). Therefore, as suggested by Comissão de Fertilidade do Solo do Estado de Minas Gerais (1999), to recommend phosphorus fertilization based in P-rem content, analytical determinations of this attribute are necessary periodically, since these values can change depending on the adopted soil practices.

For the four soils studied, except for MG, regardless of soil corrective practices, the lowest MPAC were observed for organic residue treatments. Despite of organic residue addition, the lowest MPAC values were verified for the $M G$ and $G X$ soils, for treatments with limestone and gypsum, and for the OY and RU soils, for limestone and without corrective treatments, respectively.

Regardless of soil corrective practices, organic residue treatments presented the lowest MPAC values (Figure 4). MPAC decrease caused by residue addition was $19.16 \%, 1.36 \%, 43.80 \%$ and $25.78 \%$, respectively to OY, MG, GX and RU soils.

lyamuremye et al. (1996) also verified significant effect of organic residue and calcium carbonate on MPAC decrease. Gypsum was less effective. Mechanisms responsible for this reduction are CCC: competitive adsorption between $\mathrm{P}$ and organic acids produced during mineralization, exchangeable Al complexation by organic acids (Hue, 1991). In addition, organic residues can have significant amounts of organic ligand, like sulfate and/or fluorine, and metals as $\mathrm{Ca}^{2+}$ and/or $\mathrm{Mg}^{2+}$, which are released during the mineralization process (lyamuremye et al., 1996). Sulfate and fluorine could form complexes with exchangeable Al. Calcium could form soluble complexes with the $\mathrm{P}$ present on soil solution, avoiding its adsorption. Our results showed that MPAC could be attributed to soil $\mathrm{pH}$ increase due to organic residue addition. Soil $\mathrm{pH}$ increase minimizes $\mathrm{Al}^{3+}$ activity and enhances $\mathrm{OH}^{-}$ion production, which compete with phosphorus for adsorption sites, as discussed to P-rem. Silva et al. (1997) also verified an inverse correlation between MPAC and organic matter content.

We verified a negative correlation between MPAC and $\mathrm{pH}$, and a positive correlation between MPAC and exchangeable $\mathrm{Al}$ (Table 4). It indicates that $\mathrm{pH}$ and exchangeable $\mathrm{Al}$ were related to $\mathrm{P}$ adsorption by soils,

Table 4 - Linear correlation coefficients for remaining phosphorus (P-rem), $\mathrm{pH}$, exchangeable Al, maximum phosphate adsorption capacity (MPAC) and phosphorus-buffering index (PBI).

\begin{tabular}{lccccc}
\hline & P-rem & $\mathrm{pH}$ & $\mathrm{Al}$ & $\mathrm{MPAC}$ & $\mathrm{PBI}$ \\
\hline P-rem & 1 & $0,69^{* *}$ & $-0,78^{* *}$ & $-0,98^{* *}$ & $-0,92^{* *}$ \\
$\mathrm{pH}$ & - & 1 & $-0,79^{* *}$ & $-0,64^{* *}$ & $-0,60^{* *}$ \\
$\mathrm{Al}$ & - & & 1 & $0,74^{* *}$ & $0,80^{* *}$ \\
$\mathrm{MPAC}$ & - & - & & 1 & $0,94^{* *}$ \\
$\mathrm{PBI}$ & - & - & - & - & 1 \\
\hline
\end{tabular}

** Significant at $1 \%$ by $\mathrm{t}$ test.

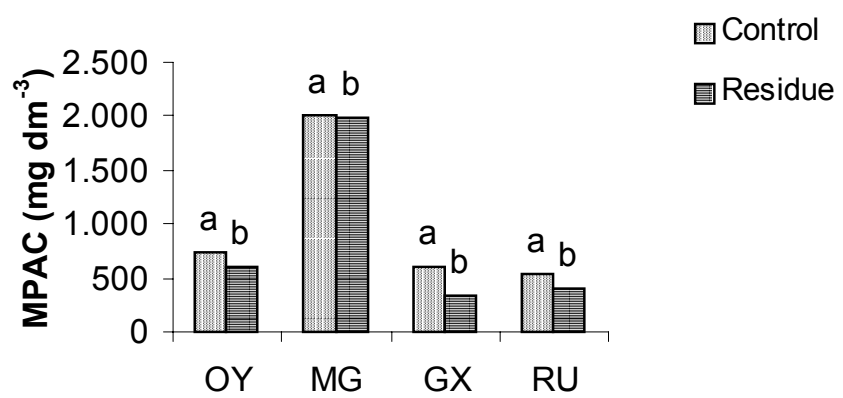

Figure 4 - Maximum phosphate adsorption capacity (MPAC) values for Mesic Organosol (OY), Melanic Gleysol (MG), Haplic Gleysol (GX) and Fluvic Neosol (RU) soils, without (control) or with organic residue addition, regardless corrective practices used. For each soil, means followed by same letter are not significantly different (Test $F, p<0.01$ )

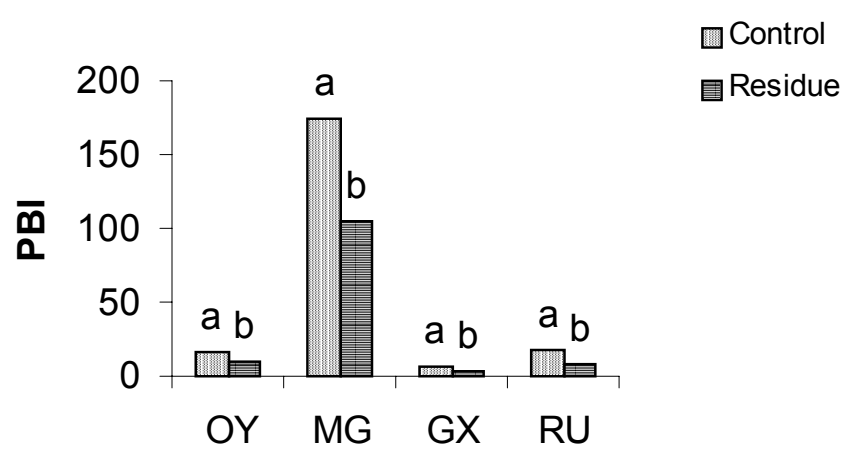

Figure 5 - Phosphorus - buffering index (PBI) values for Mesic Organosol (OY), Melanic Gleysol (MG), Haplic Gleysol $(\mathrm{GX})$ and Fluvic Neosol (RU) soils, without (control) or with organic residue addition, regardless corrective practices used. For each soil, means followed by same letter are not significantly different (Test $F, p<0.01$ ). 
as discussed for P-rem, which presented a negative correlation with MPAC.

Analyzing $\mathrm{PBI}$ values, it is possible to estimate soil capacity in restoring soluble P. In our experiment, PBI presented similar behavior to MPAC, as verified by positive correlation between these attributes (Table 4). Treatments with residue, despite of corrective practices, presented lowest $\mathrm{PBI}$ values (Figure 5).

An inverse relation of $\mathrm{PBI}$ and $\mathrm{P}$-rem were observed (Table 4). Due to its methodological facility, Prem is a good indicator of soil capacity in restoring soluble $P$ and can also be used to establish critical $P$ levels for plants, as suggested by Muniz et al. (1985).

\section{CONCLUSIONS}

Addition of organic residue and limestone (due to increase of $\mathrm{pH}$ and decrease of exchangeable $\mathrm{Al}$ content) and gypsum (due to the decrease of exchangeable Al content) reduces phosphorus adsorption by the lowland soils studied.

Highest reduction of phosphorus adsorption is reached when organic residue and limestone were applied together.

\section{REFERENCES}

ACCIOLY, L.J.O.; DAL BÓ, M.A.; ALVAREZ V., V.H.; RIBEIRO, A.C. Métodos para determinação do potencial de sulfato em solos. Revista Brasileira de Ciência do Solo, v.9, p.103-106, 1985.

ALVA, A.K.; SUMNER, M.E.; Alleviation of aluminum toxicity to soybeans by phosphogypsum or calcium sulfate in dilute nutrient solutions. Soil Science, v.147, p.278-285, 1989

ALVAREZ V., V.H.; FONSECA, D.M. Definição de doses de fósforo para determinação da capacidade máxima de adsorção de fosfatos e para ensaios em casa de vegetação. Revista Brasileira de Ciência do Solo v.14, p.49-55, 1990

ALVAREZ V., V.H.; NOVAIS, R.F. de; DIAS, L.E.; OLIVEIRA, J.A. de; Determinação e uso do fósforo remanescente. Boletim Informativo da Sociedade Brasileira de Ciência do Solo, v.25, p.27-32, 2000.

AZEVEDO, W.R. de. Níveis críticos de boro em rabanete cultivado em solos de várzea do sul de Minas Gerais. Lavras, 1999. 53p. Dissertação (Mestrado) - Universidade Federal de Lavras.

BRAGA, J.M.; DEFELIPO, B.V. Determinação espectrofotométrica de fósforo em extratos de solo e material vegetal. Revista Ceres, v.21, p.73-85, 1974.

COMISSÃO DE FERTILIDADE DO SOLO DO ESTADO DE MINAS GERAIS. Recomendação para o uso de corretivos e fertilizantes em Minas Gerais: $5^{a}$ aproximação. Viçosa, 1999. 359p.

EMPRESA BRASILEIRA DE PESQUISA AGROPECUÁRIA. Centro Nacional de Pesquisa de Solos. Sistema brasileiro de classificação de solos. Rio de Janeiro: Embrapa Solos, 1999. 412p.

EMPRESA BRASILEIRA DE PESQUISA AGROPECUÁRIA. Serviço Nacional de Levantamento e Conservação de Solo. Levantamento de reconhecimento de média intensidade dos solos e avaliação da aptidão agrícola das terras do Triângulo Mineiro. Rio de Janeiro: EMBRAPA, CNLCS. 1982. 526p. (Boletim de Pesquisa, 1)

EMPRESA BRASILEIRA DE PESQUISA AGROPECUÁRIA. Serviço Nacional de Levantamento e Conservação de Solo. Manual de métodos de análise de solo. Rio de Janeiro: Ministério da Agricultura, 1997. 212p.

FERNANDES, L.A. Formas de alumínio, de fósforo e fosfatase ácida em solos de várzea cultivados com feijoeiro: influência de calagem e fósforo. Lavras, 1999. 111p. Tese (Doutorado) - Universidade Federal de Lavras.

FERNANDES, L.A.; FAQUIN, V.; FURTINI NETO, A.E.; CURI, N. Frações de fósforo e atividade da fosfatase ácida em plantas de feijoeiro cultivadas em solos de várzea. Revista Brasileira de Ciência do Solo, v.24, p.561571,2000
FONTES. M.R.; WEED, S.B.; BOWEN, L.H. Association of microcrystalline goethite and humic acid in some oxisols from Brazil. Soil Science Society of America Journal, v.56, p.982-990, 1992

FREIRE, J.C.; RIBEIRO, M.A.V.; BAHIA, V.G.; LOPES, A.S.; AQUINO, L.H. Resposta do milho cultivado em casa de vegetação a níveis de água em solos da região de Lavras (MG) Revista Brasileira de Ciência do Solo v.22, p.5-8, 1980 .

GOH, T.B.; HUANG, P.M.; Changes in thermal stability and acidic characteristics of hydroxy-Al-montmorillonite complexes formed in the presence of citric acid. Canadian Journal of Soil Science, v.65, p.519522, 1985

GUILHERME, L.R.G.; CURI, N.; SILVA, M.L.N.; BRENÓ, N.B.; MACHADO, R.A.F. Adsorção de fósforo em solos de várzea do estado de Minas Gerais. Revista Brasileira de Ciência do Solo, v.24, p.27-34, 2000.

HARGROVE, W.L.; TOMAS, G.W. Effect of organic matter on exchangeable aluminum and plant growth in acid soils. In: STELLY, M. (Ed.) Chemistry in the soil environment. Madison: ASA, 1981. p.151-166.

$\mathrm{HUE}$, N.V. Interaction of $\mathrm{Ca}\left(\mathrm{H}_{2} \mathrm{PO}_{4}\right)_{2}$ applied to an Oxisol and previous sludge amendment: soil and crop response. Communications in Soil Science and Plant Analysis, v.20, p.1499-1511, 1990.

HUE, N.V. Effects of organic acids/anions on $\mathrm{P}$ sorption and phytovailability in soils with different mineralogies. Soil Science, v.152, p.463-471, 1991.

HUE, N.V. Correcting soil acidity of a highly weathered ultisol with chicken manure and sewage sludge. Communications in Soil Science and Plant Analysis, v.23, p.241-264, 1992.

IYAMUREMYE, F. DICK, R.P. Organic amendments and phosphorus sorption by soils. Advances in Agronomy, v.56, p.139-185, 1996.

IYAMUREMYE, F.; DICK, R.P.; BAHAM, J. Organic amendments and phosphorus dynamics: I. phosphorus chemistry and sorption. Soil Science v.161, p.426-435, 1996.

LINDSAY, W.L. Chemical equilibria in soils. New York: John Wiley \& Sons, 1979. 449p.

MCLEAN, E.O. Testing soils for $\mathrm{pH}$ and lime requirement. In: WALSH, L.M.; BEATON, J.D. (Ed.) Soil testing and plant analysis. Madison: ASA, 1973 p.78-83

MALAVOLTA, E.; VITTI, G.C.; OLIVEIRA, S.A. de. Avaliação do estado nutricional das plantas: princípios e aplicações. Piracicaba: Potafos, 1997. 210p

MEHRA, O.P.; JACKSON, N.L. Iron oxide removal from soils and clays by a dithionite-citrate system buffered with sodium bicarbonate. Clays and Clays Minerals, v.3, p.317-327, 1960

MUNIZ, A.S.; NOVAIS, R.F.; BARROS, N.F.; NEVES, J.C.L. Nível crítico de fósforo na parte aérea da soja como variável do fator capacidade de fósforo. Revista Brasileira de Ciência do Solo, v.9, p.237-244, 1985.

NAHAS, E. Ciclo do fósforo: transformações microbianas. Jaboticabal: FUNEP, 1991.67p.

PONNAMPERUMA, F.N. The chemistry of submerged soils. Advances in Agronomy, v.24, p.28-96, 1972.

RAJAN, S.S.S.; FOX, R.L. Phosphate adsorption by soils: II. Reactions in tropical acid soils. Soil Science Society of America Proceedings, v.39, p.846-851, 1975.

RITCHEY, K.D.; SOUZA, M.G.; LOBATO, E.; CORREA, A. Calcium leaching to increase rooting depth in a Brazilian Savannah Oxisol. Agronomy Journal, v.72, p.40-44, 1980

SAH, R.N.; MIKKELSEN, D.S.; HAFEZ, A.A. Phosphorus behavior in flooded drained soils: II. Iron transformation and phosphorus sorption. Soil Science Society of America Journal, v.53, p.1729-1732, 1989a.

SAYAL, S.K.; DE DATTA, S.K. Chemistry of phosphorus transformations in soil. Advances in Soil Science, v.16, p.2-120, 1991.

SIBANDA, H.M.; YOUNG, S.D. Competitive adsorption of humic acids and phosphate on goethite, gibbsite and two tropical soils. The Journal of Soil Science, v.37, p.197-204, 1986.

SILVA, M.L.N.; CURI, N.; BLANCANEAUX, P.; LIMA, J.M. de; CARVALHO A.M. de. Rotação adubo verde - milho e adsorção de fósforo em latossolo vermelho-escuro. Pesquisa Agropecuária Brasileira, v.32, p.649-654, 1997.

SPERBER, J.I. The incidence of apatite-solubilizing organisms in the rhizosphere and soil. Australian Journal of Agricultural Research, v.9, p.778-781, 1958.

SYERS, J.K.; BROWMAN, M.G.; SAMILLE, G.W.; COREY, R.B. Phosphate sorptions by soils avaluted by Langmuir adsorption equation. Soil Science Society of America Proceedings, v.37, p.358-363, 1973.

WILLETT, I.R.; HIGGINS, M.L. Phosphate sorption by reduced and reoxidized rice soils. Australian Journal of Soil Research, v.16, p.319-326, 1978.

$\overline{\text { Received May }}$ 21, 2001 